\title{
Pelaksanaan Cannal Blocking Sebagai Upaya Restorasi Gambut di Kabupaten Meranti Provinsi Riau
}

\author{
The Implementation of Canal Blocking as the Attempt of Restoring Turf in Meranti \\ Regency of Riau Province
}

Febri Yuliani

Fakultas Ilmu Sosial dan Ilmu Politik Universitas Riau

febby_Sasha@yahoo.co.id

\begin{abstract}
Abstrak
Indonesia memiliki Lahan Gambut terluas (14,9 juta ha) ke 4 di dunia setelah Kanada, Rusia, dan Amerika Serikat dan merupakan Lahan gambut tropika terluas di dunia. Indonesia menyimpan cadangan Karbon Gambut mencapai 46 giga ton, atau sekitar 8-14\% dari Karbon yang terdapat dalam gambut dunia. Manfaat ekosistem gambut antara lain adalah untuk: Kehutanan, Pengendali Banjir dan suplai air, Potensi wisata, Mata pencaharian Masyarakat lokal (perikanan, pertanian, perkebunan), Stabilisasi iklim, Keanekaragaman hayati, serta untuk Pendidikan dan penelitian. Kebakaran lahan dan hutan yang terjadi setiap tahun di Provinsi Riau hingga tahun 2016 mencapai mencapai 3.218 hektar dengan jumlah titik api terbanyak yaitu di Kabupaten Rokan Hilir dengan jumlah 32 titik. Titik api yang lain juga tersebar di Kabupaten Pelalawan, Meranti, Rokan Hulu, Bengkalis, Inhil, dan Inhu. Sementara itu kebakaran hutan dan lahan gambut diwilayah pesisir timur juga terus berlanjut. Hingga kini, tercatat sudah 310,25 hektar lahan gambut sudah terbakar di Kabupaten Meranti.Penelitian ini bertujuan untuk mengetahui pelaksanaan cannal blocking sebagai upaya restorasi gambut di Kabupaten Meranti Provinsi Riau. Jenis penelitian ini adalah kualitatif dengan metode eksploratif. Dalam pembangunan canal blocking sebagai upaya restorasi Gambut serta sebagai solusi pencegahan kebakaran lahan gambut di Kabupaten Meranti telah terlaksana Hal ini dapat dilihat dari indikator pengelolaan yang digunakan dalam menganalisis pembangunan canal blocking di Kabupaten Meranti. Terbukti dengan terjadinya penurunan titik api dibeberapa desa bahkan pada tahun 2016 tidak ditemukan titik api di Desa Sungaitohor. Selain itu dengan canal blocking lahan-lahan gambut ini kembali di tata agar dapat kembali pada fungsinya. Maka layaklah desa Sungaitohor menjadi desa percontohan dalam merestorasi gambut dan mencegah kebakaran lahan gambut.
\end{abstract}

Kata Kunci: Canal Blocking, Kebakaran Lahan dan Hutan, Restorasi Gambut

\begin{abstract}
Indonesia has the fourth widest turf area (14.9 millions ha) in the world following Canada, Russia, and United State of America and is the widest tropic turf area in the world. Indonesia stores turf carbon reserve of 46 giga ton or about $8-14 \%$ of carbon existing in the world's turf. The advantages of turf ecosystem are: forestry, controlling flood and water supply, tourism potency, livelihood for local people (fishery, farming, plantation), climate stabilization, living
\end{abstract}


diversity, and education and research. Land and forest fire occurring yearly in Riau Province up to 2016 has reached 3,218 hectares with the larges number of fire points in Rokan Hilir Regency (32 points). The other fire points were also distributed in Pelalawan, Meranti, Rokan Hulu, Bengkalis, Inhil and Inhu Regency. Meanwhile, forest and turf area fire in eastern coastal area still continues. Until today, 310.25 hectares of turf area have been fired in Meranti Regency. This research aimed to find out the implementation of canal blocking as the attempt of restoring the turf in Meranti Regency of Riau Province. This study was a qualitative research using exploratory method. The construction of canal blocking has been implemented as the attempt of restoring the turf to be the solution to prevent the turf area fire in Meranti Regency. It can be seen from the indicator of management used in analyzing the construction of canal blocking in Meranti Regency. It could be seen from the decrease of fire points in some villages and even no fire point was found in Sungaitohor Village in 2016. In addition, through canal blocking the turf was rearranged in order to restore its function. Therefore, it is reasonable that Sungaitohor village becomes model village in restoring the turf and preventing the turf land fire.

Keywords: Canal Blocking. Land and Forest Fire, Turf Restoration

\section{Pendahuluan}

Persoalan gambut di Provinsi Riau telah lama menjadi bahasan anatara lain tahun 1945: Produksi tanaman pangan lahan basah di Provinsi Riau dimulai oleh pendatang Suku Banjar dan hal ini mulai berlakunya drainase rawa pasang surut dengan pembuatan saluran primer dan sekunder.

Tahun 1950: Orang Bugis dari Sulawesi Selatan menanam tanaman utama padi dan kelapa. Tahun 1980: Reklamasi lahan basah untuk tanaman padi meningkat setelah dibangunnya pemukiman transmigrasi, meliputi Program PIR kelapa di tanah gambut menjadi tanaman utama dan pengembangan industri perkebunan kelapa dan pabriknya dari kelompok Pulau Sambu.

Selanjutnya berkembang pada Hutan Tanaman Industri (Sektor kehutanan): Kecamatan Bukit Batu Kabupaten Bengkalis, Tanaman Padi (Sektor Pertanian Tanaman Pangan) Kawasan Pertanian Tanaman pangan Pasang Surut di Kabupaten Indragiri Hilir Tanaman Kelapa Rakyat (Sektor Perkebunan) dimana terdapat di Kabupaten Indragiri Hilir dengan sistem Trio Tata Air untuk menjaga kestabilan air. Trio Tata Air: pembangunan kanal, pembuatan tanggul, dan pemasangan pintu air.

Bentang alam Asia Tenggara terdiri dari pegunungan, hutan rimba tropis, dataran rendah, rawa gambut dan perkebunan.Indonesia adalah negara kepulauan yang sangat kaya akan sumber daya alam terutama hutan. Hutan Indonesia merupakan hutan terluas ke-3 di dunia setelah Brazil dan Zaire. Luas hutan di Indonesia diperkirakan mencapai 120,35 juta hektar atau sekitar 63 persen luas daratan. Penyebaran hutan di Indonesia hampir berada di seluruh wilayah nusantara, termasuk Provinsi Riau.Maka dari itu, Indonesia merupakan salah satu paru-paru bagi seluruh negara di dunia, yaitu tempat berbagai flora dan fauna, hasil tambang serta berbagai sumber daya lainnya yang kita dapatkan dari hutan. 
Hutan juga merupakan sumber daya alam yang memberikan manfaat besar bagi kesejahteraan manusia, baik manfaat tangible ataupun intangible.Manfaat tangible atau manfaat langsung hutan antara lain kayu, hasil hutan ikutan dan lain-lain. Sedangkan manfaat intangible atau manfaat tidak langsung hutan antara lainpengaturan tata air, rekreasi, pendidikan, kenyamanan lingkungandan lain-lain (Affandi \& Patana dalam Latifah, 2004).

Selanjutnya Arief (2001) menjelaskan manfaat tangible diantaranya berupa hasil kayu dan non kayu.Hasil hutan kayu dimanfaatkan untuk keperluan kayu perkakas, kayu bakar dan pulp. Sedangkan hasil-hasil hutan yang termasuk non kayu antara lain rotan, kina, sutera alam, kayu putih, gondorukem dan terpenting, kemenyan dan lain-lain. Berdasarkan kemampuan untuk dipasarkan, manfaat hutan juga dapat dibedakan menjadi dua, yaitu manfaat marketable dan manfaat non-marketable. Manfaat hutan nonmarketable adalah barang dan jasa hutan yang belum dikenal nilainya atau belum ada pasarnya, seperti beberapa jenis kayu lokal, kayu energi, binatang, dan seluruh manfaat intangible hutan. Karena pentingnya fungsi hutan bagi kehidupan manusia sehingga kelestarian hutan tersebut perlu dijaga.

Begitupun dengan lahan gambut di Indonesia yang memberi banyak manfaat. Lahan gambut bagi Indonesia memiliki nilai yang sangat penting karena menyediakan hasil hutan berupa kayu dan non kayu, menyimpan dan mensuplai air, menyimpan karbon, dan merupakan habitat bagi keanekaragaman hayati dengan berbagai jenis flora dan fauna langka yang hanya ada dijumpai pada ekosistem ini. Sejalan dengan meningkatnya pertambahan penduduk dan keterbatasan ketersediaan lahan untuk pengembangan berbagai sektor, seperti pertanian dan perkebunan untuk memenuhi ketahanan pangan, hutan tanaman industri (HTI) untuk industri kertas, maupun untuk pemukiman penduduk dan infrastruktur lainnya, menyebabkan pilihan mulai diarahkan pada lahan gambut.

Lahan gambut adalah salah satu jenis lahan marjinal yang dipilih terutama oleh perkebunan besar, karena relatif lebih jarang penduduknya sehingga kemungkinan konflik tata guna lahan relatif kecil. Meskipun lahan gambut memiliki fungsi yang sangat strategis, namun karena Indonesia adalah produsen sekaligus konsumen utama untuk komoditi kayu, industri kertas, dan kelapa sawit dunia, menyebabkan alih fungsi atau reklamasi disertai pembuatan drainase lahan gambut alami di Indonesia tidak dapat dihindari. Alih fungsi lahan gambut telah terjadi semenjak beberapa dekade terakhir dan masih terus berlangsung sampai sekarang.

Hutan-hutan rawa gambut ini makin lama makin banyak ditebang dan diganti oleh perusahaan perkebunan dengan kayu dan terutama kelapa sawit. Untuk memproduksi kelapa sawit, permukaan air di tanah-tanah rawa itu harus diturunkan lewat drainase. Oleh karena drainase ini tanah gambut organik akan mengering, menjadi sensitif terhadap api dan kebakaran.

Untuk mendirikan perkebunan, kanal drainase digali untuk mengeluarkan airnya. 
Setelah airnya dikeluarkan, bahan organik yang didrainase akan dipecah dan dibuang sebagai karbondioksida ke udara. Ini menyumbang pada perubahan iklim. Apalagi bila aktivitas penebangan hutan dilakukakn dalam skala besar. Kanal-kanal dan parit-parit dijadikan jalur transportasi masyarakat dan potongan kayu. Hal ini akan mengakibatkan air mengalir keluar dari kubah gambut dan air akan semakin berkurang. Kehilangan air pada tanah karbon menyebabkan penyurutan dari 3$5 \mathrm{~cm}$ per tahun bagi tanah gambut itu. Ini lah membuat bentang alam tambah sensitif terhadap banjir selama musim hujan. Pada musim kemarau oksidasinya akan berlanjut dan permukaan tanah menjadi makin lama menjadi makin rendah. Inilah yang menyebab kan kebakaran dilahan gambut akan sangat rentan.

Ditambah lagi belum adanya teknologi pembukaan lahan yang murah, mudah dan cepat mendorong masyarakat untuk melakukan pembakaran ketika mempersiapkan lahannya untuk usaha pertanian atau perkebunan. Kegiatan pembukaan lahan yang kurang bijaksana, yang dilakukan masyarakat lebih dikarenakan kondisi sosial ekonomi dan adanya anggapan bahwa abu sisa pembakaran bisa menjadi pupuk. Selain itu, adanya perusahaan Hutan Tanaman Industri (HTI) dan Perkebunan yang memanfaatkan masyarakat secara sembunyi-sembunyi melakukan pembukaan lahan dengan cara membakar, agar biaya pembukaan lahan dapat ditekan, juga telah memicu terjadinya kebakaran lahan dan kebun.

Hutan-hutan tropis basah yang belum terganggu, umumnya benar-benar tahan terhadap kebakaran dan hanya akan terbakar setelah periode kemarau yang berkepanjangan. Namun sebaliknya, hutanhutan yang telah dibalak dan mengalami degradasi serta ditumbuhi semak belukar, jauh lebih rentan terhadap kebakaran.

Atas hal tersebut diatas pada dasarnya masyarakat petani/peladang, pengusaha Hutan Tanaman Industri (HTI) dan perkebunan besar meningkatkan resiko kebakaran hutan dan lahan dan dampak buruk yang diakibatkannya termasuk terjadinya bencana asap. Berbagai upaya pengendalian telah dilakukan oleh Pemerintah Pusat dan Daerah, seperti pemantauan titik panas, penyusunan dan sosialisasi Peraturan Perundangan, pembentukan lembaga - lembaga pengendalian kebakaran hutan dan lahan, melakukan koordinasi vertikal-horizontal atau pusat-daerah, kampanye, penyuluhan, apel siaga, patroli pencegahan, inventarisasi penyebab kebakaran dan pembuatan peta rawan kebakaran. Meskipun demikian, kebakaran hutan dan lahan tetap berlangsung setiap tahunnya dengan frekuensi kebakaran cenderung semakin meningkat dan biasanya berhenti seiring hujan turun.

Kebakaran gambut adalah akibat pemanfaatan rawa gambut yang tidak bertanggung jawab. Kanal-kanal yang dibangun oleh perusahaan menyebabkan lahan gambut menjadi rusak dan kering serta menjadi mudah terbakar. Berkaca pada bencana kabut asap tahun sebelumnya, seharusnya pemerintah punya solusi ampuh untuk mengatasi maslah kebakaran lahan. Namunnya nyatanya keterbatasan air masih menjadi masalah klasik. 
Terbatasnya ketersediaan air pada saat pemadaman kebakaran menimbulkan inisiatif masyarakat seperti yang dilakukan oleh masyarakat Desa Sungaitohor. Pembangunan sekat pada kanal dapat menjadi alternatif pilihan untuk mengantisipasi kebakaran dilahan gambut. Kanal-kanal yang ada pada lahan gambut ditutup saat terjadi musim kemarau sehingga tanah tetap lembab dan jika terjadi kebakaran sumber air tersedia. Pembangunan sekat kanal di Sungai Tohor ini sangat diapresiasi, bahkan pada saat kunjungan Presiden Joko Widodo.

Sungaitohor merupakan sebuah desa yang terletak di sebuah pulau bernama Tebingtinggi Timur, Kabupaten Kepulauan Meranti, Riau yang setiap tahun hutannya membara dan asapnya menutupi desa dan kota hingga ke negara tetangga. Desa ini diberkahi hutan rawa gambut yang lebat dengan tingkat keanekaragaman-hayati yang tinggi. Di antara pohon alam yang tumbuh di pulau ini terdapat pohon rumbia (sagu). Pohon ini memberikan berkah yang amat besar menopang perekonomian warganya.

Di Desa Sungai Tohor pohon rumbia (sagu) tumbuh subur di hutan-hutan yang tanahnya basah. Pertumbuhan pohon jenis ini bergantung pada basahnya tanah dan gambut. Pohon-pohon inilah yang membuat warga Sungaitohor memiliki penghidupan yang stabil. Namun, galian kanal yang di bangun secara besar-besaran oleh perusahaan dan oleh pemerintah tahun 2007 yang kedalamannya kini semakin jauh ke bawah tanah dan mengakibatkan kekeringan pada hamparan kawasan gambut. Proses pengeringan hamparan hutan gambut itu pun terjadi secara ekstrim yang menyebabkan rentannya terjadi kebakaran hutan.

Kebakaran lahan gambut lebih berbahaya dibandingkan dengan kebakaran pada lahan kering (tanah mineral). Api kebakaran di lahan gambut memiliki karakteristik selain dapat menghasilkan api tajuk dan permukaan, juga dapat menimbulkan api bawah tanah gambut yang menghasilkan asap tebal sehingga banyak merugikan berbagai pihak. Selain kebakaran vegetasi dipermukaan, lapisan gambut juga terbakar dan bertahan lama, sehingga menghasilkan asap tebal akibat pembakaran yang tidak sempurna.

Dampak asap terhadap lingkungan dapat bervariasi mulai dari yang bersifat lokal, yaitu menghalangi pemandangan sampai dengan yang memungkinkan terjadinya pemanasan iklim global. Dampak buruk yang terjadi akibat kebakaran lahan meliputi berbagai sektor kehidupan, mulai dari gangguan kehidupan sehari-hari masyarakat, hambatan transportasi, kerusakan ekologis, penurunan tingkat kunjungan pariwisata, dampak politik, ekonomi sampai pada gangguan terhadap kesehatan.

Kebakaran hutan gambut Sungai Tohor pada awal tahun 2014 berhasil dipadamkan setelah dilakukannya rekayasa hujan buatan atas perintah Presiden Susilo Bambang Yudhoyono serta berhasil menurunkan hujan deras selama tiga hari dalam rangka operasi pemadaman api. Namun pada pertengahan Januari 2015, api kembali membakar hutan di sejumlah titik di konsesi perusahaan sagu di Pulau Tebingtinggi, tak jauh dari Sungaitohor. Konsesi perusahaan itu merupakan satu hamparan dengan areal milik PT. LUM 
yang sudah rusak. Di perusahaan sagu tersebut, kanal besar juga dibangun, yang artinya pengeringan gambut juga sedang berlangsung dan kerusakan gambut semakin membuat hamparan itu rentan terbakar.

Melalui Perpres Nomor 1 Tahun 2016 Pemerintah pusat membentuk Badan Restorasi Gambut. Perpres ini yang mengatur pengelolaan lahan gambut dengan restorasi lahan gambut salah satunya dengan membangun sekat kanal (Canal Blocking). Canal blocking menjadi agenda nasional dalam merestorasi gambut dengan tujuan utamanya mengatasi kebakaran lahan akibat kerusakan ekosistem gambut. Mencegah kebakaran lahan gambut dengan menjaga lahan gambut tetap basah dianggap merupakan langkah yang lebih bijaksana dari pada penanggulangan yang menghabiskan tenaga.

Desa Sungai Tohor dipilih karena pada hari Sumpah Pemuda 28 Oktober 2015 lalu Presiden RI menerima sebuah petisi dari masyarakat daerah tersebut yang mengundang orang nomor satu di RI tersebut untuk blusukan guna melihat dampak luas pascakarhutla terbesar sepanjang sejarah di Kabupaten Kepulauan Meranti. Sungaitohor sendiri dipilih selain menjawab petisi masyarakat di sana, juga merupakan barometer penanganan di daerah lainnya di Riau serta sebagai contoh penanganan di Tanah Air.

Dengan memanfaatkan momentum pertama Presiden yang memiliki perhatian terhadap penanganan kabut asap yang disebabkan oleh kebakaran hutan dan lahan yaitu dengan melihat daerah-daerah yang memang masyarakatnya punya keinginan untuk keluar dari problemproblem gambut rusak dan kebakaran. Itulah sebabnya di pilih Desa Sungaitohor, Kecamatan Tebingtinggi Timur. Presiden diberikan alternatif atau pilihan terhadap kegiatan-kegiatan perbaikan gambut, salah satunya yang paling mudah dipahami masyarakat dan yang paling simple dilihat oleh Presiden yaitu sekat kanal (canal blocking).

Apabila kita lihat sebelumnya, ternyata pembangunan canal blocking ini telah dilakukan yaitu sejak tahun 2000 sudah ada di Kalimantan dan beberapa daerah lain di Indonesia. Sekat kanal tersebut sebelumnya dibangun berbasiskan inisiatif local masyarakat dan inisiatif NGO. Namun pada kenyataannya, canal blocking yang di bangun di Sungai Tohor ini lah yang berhasil menarik perhatian pemerintah bahkan Presiden sehingga dianggap bagus dan berhasil dalam menjawab solusi dari maslah kabut asap akibat kebakaran hutan dan lahan. Terbukti dengan berkurangnya kebakaran yang terjadi di Desa Sungai Tohor bahkan berhasil mencapai Zero Hotspot pada tahun 2016.

\section{Metode Penelitian}

\section{a. Jenis Penelitian}

Jenis penelitian ini adalah kualitatif dengan metode eksploratif. Penelitian kualitatif dengan metode eksploratif adalah suatu jenis penelitian yang bersifat terbuka, masih mencari-cari dan belum mempunyai hipotesa, pengetahuan penelitian tentang gejala yang ingin diteliti masih kurang, sehingga penelitian dengan metode eksploratif ini dilakukan sebagai langkah 
pertama untuk penelitian penjelasan maupun deskriptif. Melalui eksploratif tersebut masalah penelitian dapat digali dengan jelas dan lebih rinci. Peneliti berusaha untuk mengungkapkan masalahmasalah sesuai dengan kenyataan yang ada tanpa melakukan intervensi terhadap kondisi yang ada.

\section{b. Lokasi Penelitian}

Adapun lokasi dilakukannya penelitian ini adalah di Desa Sungai Tohor, Kecamatan Tebingtinggi Timur, Kabupaten Kepulauan Meranti, Riau. Alasan penulis memilih lokasi tersebut adalah dikarenakan Desa Sungaitohor merupakan desa yang menjadi sasaran kujungan Presiden Joko Widodo untuk menjawab "Petisi Blusukan Asap Presiden ke Riau" dan inisiatif warga Sungaitohor membuat sekat-sekat kanal agar lahan gambut tetap basah sehingga tidak mudah terbakar atau dibakar sangat diapresiasi dan kini Desa Sungaitohor menjadi pusat kajian restorasi gambut di provinsi Riau. Sungaitohor juga di jadikan kawasan Laboratorium Internasional Restorasi Gambut Tropis pertama di dunia.

\section{c. Informan Penelitian}

Informan penelitian yaitu orang-orang yang diamati dan memberikan data dan informasi, serta mengetahui dan mengerti masalah yang sedang diteliti. Data atau informasi yang diperoleh harus ditelusuri seluas-luasnya (sedalam mungkin) agar peneliti mampu mendeskripsikan fenomena yang diteliti secara utuh, maka dalam penelitian ini menggunakan informan yang dipilih secara Purposive Sampling yaitu suatu teknik penarikan informan yang digunakan dengan cara sengaja atau menunjuk langsung kepada orang yang dianggap dapat mengerti tentang masalah yang ingin diteliti. Penggunaan teknik ini senantiasa mempunyai pertimbangan-pertimbangan tertentu, yaitu peneliti harus terlebih dahulu memiliki pengetahuan tentang ciriciri tertentu siapa saja yang berkompeten memberikan informasi sesuai dengan kebutuhan penelitian.

Berikut ini adalah beberapa informan yang dianggap mengerti tentang masalah yang ingin diteliti oleh penulis:

1. Deputi IV Bidang Penelitian dan Pengembangan Badan Restorasi Gambut (BRG) Republik Indonesia.

2. Kepala Dinas Kehutanan dan Perkebunan Kabupaten Kepulauan Meranti.

3. Wahana Lingkungan Hidup Indonesia (Walhi) Riau.

4. Ketua forum masyarakat sukses restorasi gambut Sungaitohor.

5. Tokoh masyarakat Sungaitohor.

6. Masyarakat Desa Sungaitohor

\section{d. Jenis Data dan Sumber Data}

\section{Data Primer}

Data primer dalam penelitian ini adalah data hasil wawancara dan observasi sehubungan pembangunan canal blocking sebagai solusi pencegahan kebakaran lahan gambut di Desa Sungaitohor Kabupaten Kepulauan Meranti. Adapun data yang dibutuhkan peneliti untuk dianalisis yaitu: 
1. Perencanaan dari pembangunan canal blocking.

2. Pengorganisasian dari pembangunan canal blocking.

3. Penyusunan staff dari pembangunan canal blocking.

4. Pengarahan dari pembangunan canal blocking.

5. Koordinasi dari pembangunan canal blocking.

6. Pelaporan dari pembangunan canal blocking.

7. Penganggaran dari pembangunan canal blocking.

8. Pengawasan dari pembangunan canal blocking.

\section{Data Sekunder}

Data yang diperoleh untuk melengkapi data primer melalui sumber kedua atau sumber sekunder dari data yang dibutuhkan. Sumber data ini dapat diperoleh dari laporan-laporan penelitian terdahulu, jurnal,buku-buku, internet, koran, televisi dan sumber lainnya yang relevan dengan penelitian.

Data sekunder juga diperoleh dari pihak kedua secara tidak langsung yang menunjang objek yang diteliti berupa visi dan misi dari Desa tempat penelitian,gambaran umum lokasi penelitian, dan lai-lain.

\section{e. Teknik Pengumpulan Data}

Untuk memperoleh data yang akurat agar dapat menjawab permasalahan yang ada dalam penelitian ini dapat digunakan beberapa teknik pengumpulan data yaitu:

\section{Observasi}

Observasi adalah pengamatan yang dilakukan penulis secara sistematis dan sengaja dilakukan dengan menggunakan alat indera terutama mata dan telinga terhadap kejadian-kejadian yang berlangsung, dimana peneliti datang ke tempat penelitian yaitu Desa Sungaitohor untuk melakukan pengamatan terhadap masalah yang terjadi. Dalam hal ini peneliti juga melakukan observasi awal untuk melihat masalah yang terjadi. Kemudian ditindaklanjuti dengan observasi yang lebih mendalam lagi mengenai pembangunan canal blocking sebagai solusi pencegahan kebakaran lahan gambut di Desa Sungaitohor Kabupaten Kepulauan Meranti.

\section{Wawancara}

Wawancara (interview) merupakan metode yang digunakan untuk memperoleh informasi secara langsung dan dalam tidak berstruktur dan individual. Wawancara tidak berstruktur adalah wawancara dimana pewawancara dapat dengan leluasa memberikan pertanyaan dari berbagai segi dan arah untuk mendapatkan informasi secara lengkap dan mendalam. Wawancara tidak berstruktur sangatmemadai dalam penelitian kualitatif. Adapun dalam penelitian ini wawancara yang dilakukan yaitu tentang Pembangunan Canal Blocking sebagai Solusi Pencegahan Kebakaran Lahan Gambut di Desa Sungaitohor Kabupaten Kepulauan Meranti.

\section{Teknik kepustakaan}

Teknik yang dilakukan dengan cara mengumpulkan literatur maupun dokumen dari kepustakaan yang berkaitan dengan 
judul dan masalah dari penelitian yang akan dibahas. Pengumpulan data dengan cara membaca berbagai literatur seperti buku, jurnal dan pemberitaan media massa seputar masalah penelitian atau dapat juga diambil dari beberapa dokumen mengenai gambaran umum lokasi penelitian atau halhal lain yang dapat mendukung hasil penelitian.

\section{Dokumentasi}

Dokumentasi merupakan studi yang dilakukan dengan cara mengumpulkan data dan menganalisis dokumen-dokumen, baik dokumen tertulis, gambar, audio maupun elektronik.

\section{f. Analisis Data}

Analisis data adalah proses mencari dan menyusun secara sistematis data yang diperoleh dari hasil wawancara, catatan lapangan, dan bahan-bahan lain, sehingga dapat mudah dipahami. Metode analisa data yang digunakan dalam penelitian ini adalah metode analisa kualitatif eksploratif yaitu analisa data yang menggali informasi secara jelas dan terperinci berdasarkan kenyataan yang ditemukan dilapangan melalui hasil wawancara yang kemudian ditarik suatu kesimpulan agar memberikan jawaban atas permasalahan yang dikemukakan. Dalam penelitian ini peneliti menggunakan teknik triangulasi untuk pemeriksaan keabsahan data. Triangulasi secara umum merupakan kegiatan check, re-check, dan crosscheck antara data dengan observasi penelitian di lapangan yang selanjutnya selanjutnya hasil observasi ini dilakukan crosscheck melalui persepsi peneliti.

\section{Hasil dan Pembahasan}

Pengelolaan merupakan istilah yang dipakai dalam ilmu manajemen. Secara etomologi istilah pengelolaan berasal dari kata kelolah (to manage) dan biasanya merujuk pada proses mengurus atau menangani sesuatu untuk mencapai tujuan tertentu. Jadi pengelolaan merupakan ilmu manajemen yang berhubungan dengan proses mengurus dan menangani sesuatu untuk mewujudkan tujuan tertentu yang ingin dicapai.

Sukanto dalam Saputra (2013) mendefinisikan bahwa pengelolaan dalam administrasi adalah merupakan suatu proses yang dimulai dari proses perencanaan, pengawasan, penggerakan sampai dengan proses pencapaian tujuan. Sukanto pada dasarnya menitik beratkan pada fungsi-fungsi manajemen yang meliputi perencanaan, pengawasan, penggerakan agar mencapai tujuan yang diinginkan.

Sedangkan Terry dalam Brantas (2009) mengemukakan bahwa pengelolaan sama dengan manajemen sehingga pengelolahan dipahami sebagai suatu proses membedabedakan atas perencanaan, pegorganisasian, penggerakan dan pengawasan dengan memanfaatkan baik ilmu maupun seni agar dapat menyelesaikan tujuan yang telah ditetapkan sebelumnya. G.R Terry membagi sumber-sumber manajemen (tool of management) kedalam 6M, yaitu:

1. Men, tenaga kerja manusia baik tenaga kerja eksekutif maupun operatif

2. Money, uang yang dibutuhkan untuk mencapai tujuan yang diinginkan 
3. Methods, cara-cara yang digunakan dalam usaha mencapai tujuan

4. Material, bahan-bahan yang dipergunakan untuk mencapai tujuan

5. Machines, mesin-mesin atau alat-alat yang dipergunakan untuk mencapai tujuan

6. Market, pasar untuk menjual output dan jasa-jasa yang telah dihasilkan

Kegiatan manajemen tidak akan berjalan dan tujuan tidak akan tercapai jika tidak disertai dengan sumber-sumber manajemen, sumber-sumber tersebut dibedakan atas sumber daya manusia dan sumberdaya non manusia.

Selanjutnya mengenai pengertian pengelolaan Pamudji dalam Saputra (2013) mengemukakan sebagai berikut: Perkataan pengelolaan berasal dari kata kelola yang berarti sama dengan mengurus. Jadi pengelolaan diartikan sebagai pengurusan yaitu merubah nilai-nilai yang lebih tinggi, dengan demikian pengelolaan juga mengandung makna sebagai pembaharuan, yaitu melakukan usahausaha untuk membuat sesuatu lebih sesuai atau cocok dengan kebutuhan menjadi lebih baik dan lebih bermanfaat. Pendapat Pamudji diatas mengenai pengelolaan terlihat menitik beratkan pada dua faktor penting yaitu :

1. Pengelolaan sebagai pembangunan yang merubah sesuatu sehingga menjadi baru dan memiliki nilai yang lebih tinggi.

2. Pengelolaan sebagai pembaharuan yaitu usaha untuk memelihara sesuatu agar lebih cocok dengan kebutuhankebutuhan.
Luther Gullick dalam Effendi (2015) mengemukakan bahwa manajemen adalah satu bidang ilmu (science) yang dipelajari secara sistematis. Maksudnya mempelajari manajemen dengan menitik beratkan pada unsur ilmunya dalam arti manajemen digunakan sebagai ilmu pengetahuan. Adapun fungsi manajemen menurut Luther Gullick adalah Planning, Organizing, Staffing, Directing, Coordinating, Reporting, Budgeting, Controlling.

Pembangunan bertujuan untuk menaikkan tingkat hidup dan kesejahteraan manusia. Pembangunan tidak saja menghasilkan manfaat, melainkan juga membawa resiko. Betapapun baiknya manfaat, resiko harus diperhitungkan secara berimbang.Sehingga yang harus dipikirkan adalah bagaimana membangun agar sekaligus mutu lingkungan dan mutu hidup dapat ditingkatkan.

Menurut Siagian (2004) pembangunan adalah serangkaian usaha untuk mewujudkan pertumbuhan dan perubahan secara terencana dan sadar yang ditempuh oleh suatu Negara atau bangsa menuju modernitas dalam rangkaian pembinaan bangsa (nation buiding). Melakukan pembangunan berarti mempersiapkan seluruh kebutuhan masyarakat yang diindikasikan oleh potensi masyarakat. Beberapa asset yang harus dimiliki masyarakat sebagai hasil dari pembangunan dan pengembangan masyarakat mencakup asset yang diasumsikan terkait dengan upaya pengembangan fisik, modal lingkungan, modal teknologi, modal manusia dan modal sosial.

Menurut Rogers dalam Suryono (2001) pembangunan adalah suatu proses 
perubahan sosial dengan partisipatori yang luas dalam suatu masyarakat yang dimaksudkan untuk kemajuan sosial dan material (termasuk bertambah besarnya keadilan, kebebasan dan kualitas lainnya yang dihargai) untuk mayoritas rakyat melalui kontrol yang lebih besar yang mereka peroleh terhadap lingkungan mereka. Adapun pembangunan sarana fisik diartikan sebagai alat atau fasilitas yang dapat dirasakan manfaatnya secara langsung oleh masyarakat seperti yang dimaksud berupa:

1. Prasarana perhubungan yaitu: jalan, jembatan dan lain-lain.

2. Prasarana pemasaran yaitu: gedung, pasar.

3. Prasarana sosial yaitu: gedung sekolah, rumah-rumah ibadah, dan puskesmas.

\section{Prasarana produksi saluran air.}

Berdasarkan hal tersebut jelas bahwa pembangunan itu proses perubahan kearah lebih baik tersebut hanya terwujud dengan melibatkan, menggerakkan manusianya baik dalam perencanaan, pelaksanaan, pemanfaatan serta mengevaluasi hasilnya. Selain itu pembangunan merupakan suatu proses, ini dimaksudkan bahwa setiap usaha pembangunan pasti memerlukan kesinambungan pelaksanaan, dalam arti tanpa mengenal batas akhir meskipun dalam perencanaannya dapat diatur berdasarkan azas skala prioritas dan suatu tahapan tertentu.

\footnotetext{
Menurut Braratakusuma (2005) menjelaskan bahwa pelaksanaaan pembangunan semestinya tidak lagi menjadi monopoli pemerintah, melainkan juga harus menjadi tanggung jawab dan kebutuhan masyarakat, dengan demikian
}

masyarakat akan lebih merasa memiliki dan berkewajiban untuk mendorong terlaksananya proses pembangunan didaerahnya.

Menurut Scramm dan Lerner dalam Mardikanto (2013) mengungkapkan bahwa, di dalam proses pembangunan pada dasarnya terdapat dua kelompok atau sub sistem pelaku-pelaku pembangunan yang terdiri atas:

1. Kelompok kecil warga masyarakat yang merumuskan perencanaan dan berkewajiban untuk mengorganisasi dan menggerakan waraga masyarakat yang lain untuk berpartisipasi dalam pembangunan. Pengertian merumuskan perencanaan pembangunan itu, tidak berarti bahwa ide-ide atau aspirasi yang dikehendaki oleh seluruh warga masyarakat melalui suatu mekanisme yang telah disepakati disalurkan melalui pertemuan kelompok atau permusyawaratan pada lembaga yang terbawah, secara formal maupun informal.

2. Masyarakat luas yang berpartisipasi dalam proses pembangunan, baik dalam bentuk pemberian input (ide, biaya, tenaga, dll), pelaksanaan kegiatan, pemantauan dan pengawasan serta pemanfaatan hasil-hasil pembangunan. Dalam kenyataan, pelaksana utama kegiatan pembangunan justru terdiri dari kelompok ini, sedangkan kelompok elit masyarakat hanya berfungsi sebagai penerjemah kebijakan dan perencanaan pembangunan sekaligus mengorganisir dan menggerakkan partisipasi masyarakat. 
Pembangunan canal blocking tentunya mempunyai tujuan dan fungsi. Agar tujuan dan fungsi tersebut dapat tercapai dengan baik sesuai dengan sasaran yang telah ditentukan maka canal blocking harus dikelola dengan baik sesuai dengan prinsip-prinsip manajemen.Menurut Luther Gullick ada beberapa aspek yang harus diperhatikan agar manajemen berjalan dengan lancar dan mencapai hasil yang memuaskan yaitu terdiri dari Planning, Organizing, Staffing, Directing, Coordinating, Reporting, Budgeting (POSDCORB).

Tujuan dari pembangunan canal blocking adalah untuk memulihkan kembali keadaan gambut yang basah dan lembab serta menata kembali lahan-lahan gambut yang sudah terlanjur di gali.Sekat kanal (canal blocking) yang dibangun berfungsi menahan derasnya aliran air dari kubah gambut kebawah, mengarahkan aliran air itu ke samping. Dengan adanya sekat tadi, air akan mencari jalan kesamping, tidakhanya satu arah sehingga memberi efek gambut basah, serta mengurangi terjadinya pengurasan di kubah tempat sumber air.

Selain itu, sifat gambut berpori seperti spon. Yang mana apabila tidak ada air maka gambut akan mengempis, sebaliknya apabila ada air maka ia mengembang lagi. Maka dengan adanya canal blocking ini akan mempertahankan keadaan gambut agar tidak mengempis. Dan yang paling terpenting adalah pada saat kita berbica mengenai masalah kekinian yaitu isu pencegahan kebakaran dan kabut asap. Pembangunan canal blockingmerupakan upaya pencegahan munculnya atau kembalinya kebakaran lahan gambut serta tragedi kabut asap. Di samping itu dengan dibangunnya canal blocking maka ini berfungsi untuk tempat sumber air apabila terjadi kebakaran, untuk memadamkan api.Kemudian, di daerah pesisir, dareah gambut-gambut yang berhadapan langsung dengan pantai seperti di Sungaitohor, canal blocking berfungsi untuk menahan laju intrusi air asin, membantu mengurangi masuknya air asin ke daratan gambut sehingga tanaman sagu bisa tumbuh dengan bagus.

Pembangunan canal blocking secara teknis perencanaan desain pembangunannya dilakukan oleh Kementrian PUPR (Pekerjaan Umum dan Perumahan Rakyat), Ciptada (Cipta Karya, Tata ruang dan Sumber Daya Air) dan tenaga teknis ataupun orang-orang yang memiliki keahlian dibidang teknil sipil dan keilmuan air serta ada konsultannya yang dikoordinasi secara berjenjang dengan melihat status kawasannya apakah hutan ataupun perkebunan. Dimulai dari tingkat paling bawah yang dilakukan oleh Dinas Kehutanan dan Perkebunan dan KPH (Kawasan Pemangku Hutan) Tebingtinggi. Di Provinsi koordinasi dengan BLH (Badan Lingkungan Hidup) dan Ciptada, serta di tingkat Nasional koordinasi dengan BRG (Badan Restorasi Gambut) dan Kementrian Lingkungan Hidup dan Kehutanan.Dalam proses perencanaan dibahas mengenai tentative kegiatan, mekanisme pelaksanaan, strategi, kelengkapan bangunan dan pelaporan. Dalam perencanaan ini disusun, pelaksana teknis pembangunan canal blockingada dua yaitu Walhi (Wahana Lingkungan Hidup Indonesia) dan PSB (Pusat Studi Bencana) dari Universitas Riau dalam konteks yang bertanggung jawab pada 
BRG.PSB dalam hal mensupport dari sisi akademis dalam bentuk riset-riset, Walhi dalam konteks bagaimana kegiatan ini di pahami dan dilakukan oleh masyarakat, sehinggaketerlibatan dari aktivitas ini dilakukan oleh masyarakat.BRG sebagai yang punya projek dan UNDP (United Nation Development Programs) untuk mekanisme keuangan.

Sedangkan di desa perencanaannya dimulai dengan musyawarah untuk mengetahui bentuk dari canal blocking yang akan dibangun itu seperti apa, tingginya berapa, peralatan dan materil yang digunakan seperti apa dan pekerjanya siapa. Perencanaan ini dibuat oleh beberapa kelompok orang yang sudah biasa bekerja disana dan biasa membuat sekat kanal.

Tujuan yang ingin dicapai dari pembangunan canal blocking adalah untuk membasahi kembali lahan gambut yang kering akibat galian kanal sehingga dapatmencegah terjadinya bencana kebakaran dilahan gambut.Dalam pembangunan sekat kanal di butuhkan perencanaan yang matang yang tentunya ada hal-hal yang perlu diperhatikan sebagai prosedur yang dijadikan pertimbangan sebelum akhirnya dilakukan pembangunan agar tujuan ini dapat tercapai secara efektif.

Prosedur yang perlu diperhatikan adalah yang pertama, mempertimbangkan topografi letak sekat kanal yang akan dibangun. Dengan mengutamakan daerahdaerah yang topografinya tinggi dan daerah kubah yang gambutnya dalam agar air tidak terkuras habis, mengalir kebawah dan meyebabkan gambut menjadi kering sehingga mudah terbakar. Maka program yang dilakukan sebelum melakukan pembangunan adalah surve ke lapangan terlebih dahulu, menentukan dimana tempat akan dibangunnya sekat kanal yang tepat.

Kedua adalah mempertimbangkan dari aspek dampaknya kepada masyarakat dikaitkan dengan kegiatan masyarakat. Dalam hal ini diusahakan masyarakatmasyarakat yang memang paralel dengan maunya gambut itu basah, lebih kepada dampak komoditi yang sudah menghidupkan mereka seperti sagu. Untuk itu dilakukan komunikasi dan diskusi dengan masyarakat, kemudian ditentukan dan disepakati pengerjaan sekat kanal yang idealnya dilakukan oleh masyarakat setempat dengan bantuan supervisi atau pengawasan dan pemdampingan dari ahlinya misalnya bisa dari universitas, dari lembaga-lembaga pemerintah ataupun dari NGO. Agar pembangunan sekat kanal itu dapat terwujud sesuai dengan tujuan dan kebutuhan masyarakat.Hal inidianggap lebih penting, bagaimana masyarakat itu menjadi lebih memiliki, dan membangun kepedulian masyarakat.

Pada pembangunan canal blocking sebagai upaya restorasi Gambut dan solusi pencegahan kebakaran lahan gambut di Desa Sungaitohor Kabupaten Kepulauan Meranti. Dari hasil penelitian yang dilakukan dapat juga diketahui bahwa terdapat beberapa halpenguatan pada pembangunan canal blocking sebagai upaya restorasi gambut yaitu antara lain: pertama, Regulasi Pemerintah yang dilakukan melalui kebijakan BRG merupakan langkah strategis sebagai pendorong pembangunan canal blocking sebagai solusi pencegahan kebakaran lahan 
gambut di Desa Sungaitohor Kabupaten Kepulauan Meranti. Kedua, Partisipasi Masyarakat dalam pembangunan canal blocking sebagai upaya restorasi gambut dibuktikan dengan keikutsertaan dan kepedulian masyarakat dalam pembangunan canal blocking. Selain itu, bentuk partisipasi masyarakat juga dapat berupa kesadaran masyarakat itu sendiri dalam memahami kebutuhan masyarakat akan keberadaan canal blocking. keberhasilan pembangunan canal blocking tidak terlepas dari peran serta masyarakat yang merupakan subjek yang merasakan manfaat dari adanya canal blocking. Oleh karena itu, semua anggota masyarakat sudah seharusnya berpartisipasi juga dalam pemeliharaan dan pengawasan canal blocking di desa tersebut. Ketiga, Kearifan Lokal Masyarakat terhadap Gambut. mencakup semua bentuk pengetahuan, keyakinan, pemahaman atau wawasan serta adat kebiasaan atau etika yang menuntun perilaku manusia dalam kehidupan didalam komunitas ekologis. Kearifan lokal merupakan tata nilai atau perilaku hidup masyarakat local dalam berinteraksi dengan lingkungan tempatnya hidup secara arif.

Kabupaten Meranti merupakan salah satu daerah yang menghasilkan Sagu terbesar di Sumatera dengan tanaman sagu organik berbeda dengan pohon sagu yang ada di Indonesia Bagian Timur.Kebanyakan pekerjaan masyarakat Kabupaten Meranti adalah petani sagu.Membudidaya, menghasilkan sagu dan mengolah sagu menjadi makanan pokok ciri khas mereka seperti lumping sagu, simpolek sagu, telor sagu, minuman laksamana raja mengamuk, ongol-ongol dan lainnya.Ini telah dilakukan secara turun temurun.Sagu menjadi sumber penghidupan dan kebanggaan masyarakat Kabupaten Kepulauan Meranti, Provinsi Riau

Sagu yang berasal dari pohon sagu atau biasa disebut pohon rumbia merupakan makanan pokok masyarakat Sungaitohor.Ini merupakan suatu bentuk bahwa masyarakat desa Sungaitohor telah memiliki mindset ekonomi berbasis kearifan lokal untuk menjaga kelestarian hutan rawa gambut. Selain budidaya sagu, masyarakat juga telah berupaya untuk mencegah terjadinya kebakaran hutan yang meluas dengan pembuatan kanal yang diberikan sekat agar tidak terjadinya erosi tanah yang membuat kanal tidak berfungsi dengan baik.

Masyarakat Kabupaten Meranti sangat antusias dengan pertanian sagu yang memang sudah turun temurun dan merupakan kearifan lokal masyarakat setempat.Masyarakat menduga, bahwa kebakaran di Kabupaten Meranti akibat kanalisasi oleh perusahaan sehingga menyebabkan kekeringan pada gambut.Selain gambut kering mudah terbakar, ini juga mempengaruhi pertumbuhan sagu yang merupakan sumber penghidupan dan perekonomian masyarakat. Dengan adanya canal blocking ini akan menjaga gambut tetap dalam kondisi basah sehingga tidak mudah terbakar dan gambut yang basah sangat cocok dengan tanaman sagu yang karakternya memang suka hidup di lahan basah.

\section{Penutup}

Berdasarkan hasil pemaparan hasil dan pembahasan tentang Pembangunan Canal 
Blocking sebagai upaya restorasi gambut di kabupaten Meranti maka dapat disimpulkan bahwa dalam pembangunan canal blocking sebagai upaya restorasi gambut di Kabupaten Meranti dilakukan mulai dari perencanaan hingga pengawasannya. Secara lebih mendalam dapat pula teridentifikasi hal-hal yang mendorong percepatan restorasi gambut yaitu regulasi pemerintah, yang berupaya agar lahan gambut tetap basah melalui pembentukan Badan restorasi gambut (BRG). Partisipasi masyarakat yang berupa keikutsertaan dan kepedulian masyarakat dalam pembangunan canal blocking. Serta kesadaran masyarakat sebagai subjek yang merasakan manfaat dari adanya canal blocking ini. Berikutnya adalah kearifan lokal masyarakat terhadap gambut, yaitu masyarakat harus menjaga kelestarian lahan gambut yang merupakan sumber kehidupan mereka yang secara turun temurun telah memanfaatkannya untuk mengolah sagu.

Dari penelitian yang telah dilakukan, peneliti memberikan beberapa saran yang diharapkan dapat menjadi masukan yang membangun dalam pembangunan canal blocking sebagai upaya restorasi gambut, antara lain:

1. Hendaknya pemerintah maupun pihak akademisi serta NGO yang terkait dalam pembangunan canal blocking pada lahan gambut menentukan standar bentuk dari canal blocking yang baik dan cocok agar canal blocking yang dibangun dapat terukur ketahanannya.

2. Untuk memudahkan pembangunan, perlu diketahui bentuk gambut di suatu daerah yang menjadi obyek pembangunan canal blocking, penyekatannya yang baik bagaimana serta menentukan posisi atau letak sekat kanal yang akan dibangun. Maka dari itu, pemerintah juga perlu berkoordinasi dengan badan-badan penelitian serta NGO untuk membuat peta kontur wilayah dan hidrologi guna mendukung pembangunan canal blocking. Hal ini agar dana-dana yang dikeluarkan untuk pembangunan canal blocking ini lebih efektif.

3. Hendaknya pemerintah desa menganggarkan dana untuk perawatan sekat kanal yang telah dibangun agar sekat yang ada tetap terjaga dan dapat bertahan lama. Sehingga manfaat dari sekat kanal ini dapat berlangsung lama dan berkelanjutan.

4. Kiranya agar pengelolaan pembangunan canal blocking dapat lebih ditingkatkan melalui kepedulian antar instansi dan seluruh masyarakat.

5. Masyarakat diharapkn agar lebih meningkatkan partisipasinya dalam melakukan pengawasan terhadap pembangunan canal blocking dan perawatan terhadap canal blocking yang telah selesai dibangun agar dapat terjaga kelestariannya dan juga keberlangsungan manfaatnya.

\section{Daftar Pustaka}

Agung Sardjono, dan Mustofa, 2004 Mosaik Sosiologis Kehutanan : Masyarakat Lokal, Politik dan Kelestarian Sumber Daya, Yogyakarta : Debut Press.

Balibang Pemprov Riau. 2010. Seminar dan Lokakarya: Pengelolaan Terpadu 
Lingkungan Perkebunan Kelapa

Sawit Berkelanjutan di Provinsi Riau

Colchester, M., dkk., 2006, Ghosts on our Own Land: Indonesian Oil Palm Smallholders and the Roundtable on Sustainable Palm Oil, Bogor, Sawit Watch dan Forest People Programme.

Creswell, John W. 1994. Research Design: Qualitative \& Quantitative Approaches. California: Sage Publications.

Dunn, William N. 1998. Pengantar Analisis Kebijakan Publik, Edisi II. Penyunting Muhadjir Darwin. Yogyakarta: Gadjah Mada University Press.

Dunsire, Andrew. 1978. Implementation in Bureaucracy. Oxford: Martin Robertson.

Dwitho Frasetiandy. 2009 "Menakar dampak sosial perkebunan sawit" dalam andy, on 03-09-2009 20:20 Views : 1460 Popular, Favoured : 31 Dwitho Frasetiandy.

Dye, Thomas R. 1972. Understanding Public Policy. New York: PrenticeHall. Inc.

Edwards III, George C_ 1980. Implementing Public Policy. Washington: Congressional Quarterly Inc.

Faisal, Sanapiah, 2001, FormatFormat Penelitian Sosial, PT. Raja Grafindo Persada, Jakarta

Firdaus, 2012, Perlindungan Hak Masyarakat Adat Studi Terhadap Tanah Ulayat Dalam Pengelolaan Perkebunan Kelapa Sawit di
Indonesia, Prosiding Seminar Internasional, Pekanbaru

Kausar. 2010. Konflik Kepentingan Dibalik Konservasi Studi di Taman Nasional Kerinci Seblat (TNKS). Jurnal IJAE No Volume 2, Nomor 1, Desember 2010. Jurusan Agribisnis Faperta UR. Pekanbaru

Manajer Kampanye WALHI Kalsel andy@walhikalsel.org http://www.walhikalsel.org/content/v iew/131/48/

Sumardjo. 2007. Metoda Partisipatif dalam Pengembangan Masyarakat. Magister Profesional Pengembangan Masyarakat, Sekolah Pascasarjana IPB. Bogor.

Van Meter, Donal S. \& Carl E. Van Horn. 1975. The Policy Implementation Process: A Conceptual Framework. London: Sage Publications Inc.

Wahab, Solichin Abdul, 2002, Analisis Kebijaksanaan Dan Formulasi Ke lmplementasi Kebijaksanaan Negara, Bumi Aksara, Jakarta.

Wibawa, Samudera dkk, Kebijakan Publik, Proses dan Analisis, Intermedia, Jakarta, 1994

Winarno, Budi., 2002., "Teori dan Proses Kebijakan Publik"., Media Perssindo., Yogyakarta 